\title{
On the Elements of Moral Education in Ideological and Political Courses in Colleges and Universities
}

\author{
Dongju Fang* \\ Department of computer, Wuhan polytechnic, Wuhan 430074, China \\ *Corresponding author. Email:867327860@qq.com

\begin{abstract}
To promote the ideological and political construction of colleges and universities, the leading role of teachers is very important. It is necessary to integrate the moral and example role of teachers into the teaching of professional courses harmoniously, so as to truly moisten things silently, cultivate people with imperceptible morality, and implement the ideological and political course in the process of impart knowledge.
\end{abstract}

Keywords: Colleges and universities, The teacher's ethics, An example, Curriculum Ideology and Politics.

\section{INTRODUCTION}

Self-interest appeal social value pluralism, diversity of today, the college ideological and political education for college students, guide students to set up the correct world outlook, the outlook on life, values is critical, of talent cultivation in colleges and universities, scientific research, social services, cultural heritage and innovation function determines the necessity of practicing "strengthen moral education and cultivate people" thought. $80 \%$ of university teachers, however, is a professional teachers, $80 \%$ is a specialized course, student's study time by $80 \%$ for professional course study, which requires colleges and universities set up the new idea of curriculum education, giving full play to the advantages of multidisciplinary joint professional, dig more collaborative education course resources, the specialized construction and ideological and political theory course coordinated, synthetic counterparts, indepth course and education exchange, mutual melting together ${ }^{[1]}$ to achieve education goal. The ideological and political course is a new model which is based on the professional course, deeply excavates the value of the course from the dimension of education, realizes the integration of the curriculum and ideological and political course, and is committed to improving the ideological and political level of students. Xi jinping, general secretary of the ideological and political work in colleges and universities nationwide symposium speech to the concept of "course education" be the best annotations, he points out that in order to improve and enhance the ideological and political course to use good classroom teaching the main channel, in all kinds of courses teaching in ideological and political theory, professional course and the thought political lesson synthetic counterparts, form a synergistic effect. It can be seen that curriculum ideology and politics should play an educational role in all courses of colleges and universities, and all educators should assume the responsibility of educating people.

\section{TEACHER'S PERSONAL MORALITY AND LEADING ROLE}

In the course of ideological and political education for college students, the leading role of teachers is very important. The key point of moral education in colleges lies in the leading role of teachers, so we must strengthen teachers' morality and regulate teachers' words and deeds. Teachers are the backbone for the realization of the mission, and the implementation and promotion of the mission need the joint efforts of every educator. Colleges and universities should earnestly strengthen and improve the construction of teachers. The key point of running a good education is teachers. What a good teacher leaves to students is not only rich in knowledge, but also spiritual sustentation. Teachers, preach, impart knowledge and solve doubts. Since ancient times, China has emphasized the importance of teachers' ethics, which puts forward higher requirements for our teachers' moral quality and their own development. College students are in the construction period of world outlook, outlook on life and values, which is still in the imitation stage and cannot reach the level of rational analysis. However, this imitation is more about our teachers. As the old saying 
goes: keep company with dogs, you will get black. Only teachers by example, set an example, play the role of the exemplary role, consciously become the example, with theory to guide students, with the actual infection of students. General Secretary Xi Jin-ping also pointed out that students should be guided to buckle the first button of life in his speech at the school ideological and political class forum, and proposed six requirements for teachers, including strong politics, deep feelings, new thinking, broad vision, strict self-discipline and positive personality. This is to ask teachers to set an example by themselves. "To learn from a high position is to be a teacher, and to be upright is to be exemplary" is the most familiar eight words of normal majors. The development of students, universities and nations depends on teachers. Therefore, we teachers must demonstrate the fundamental requirement of implementing the cultivation of morality in universities ${ }^{[2]}$.

\subsection{Integrate Teachers' Personal Morality into Curriculum Ideology and Politics}

"To make all kinds of courses and ideological and political courses in the same direction", is not only the course content, but also people in the same direction. Professional teachers in higher vocational colleges once took teaching professional technical skills as their main business, and the mastery of exquisite technical skills is the premise for them to be respected by students in vocational colleges. Since ancient times and now, the evaluation of masters and masters has always been a dialectical combination of skill and Taoism. A real teacher is first "preaching" and then "impart knowledge" and "solve doubts". Teachers of any subject, only their own conduct, in order to continue to deepen the technical skills; Only if they are deep enough in their knowledge will the dissemination of values in their professional knowledge and technical skills come naturally and become imperceptible. In fact, the suggestion and emphasis of curriculum ideology and politics is just a manifestation of the need to improve the missionary consciousness and ability of most professional teachers. The teacher's preaching consciousness and ability are first reflected in the teacher's own virtue and character. Among all dimensions of curriculum ideology and politics, the moral character of teachers is one of the most vivid and intuitive, direct and lasting effects in educating people. The general secretary stressed that "to strengthen ethics strengthen construction, insist on teaching and education unifies, adhere to the words and teaching unifies, insist on asked with great concentration and attention social unity, adhere to the academic freedom and academic standardization unifies, guide the broad masses of teachers live morally, good learning, good for teaching" [3] pointed out the direction for us. The elucidation of the dimension of teachers' ethics in the course ideological and political philosophy is different from the bottom line compliance and implementation of the norms of teachers' ethics in the general sense, but should take the high standard of noble teachers' ethics as the benchmark and guidance for students, "better assume the responsibility of guiding students' healthy growth" ${ }^{[4]}$ Higher vocational teachers should be deeply aware that real education is not only in the knowledge class and skill training, but also in every moment and link of teacherstudent communication. Teachers must always show the power of example with their own moral sentiment, and strive to be the guide for students to temper their character from all aspects. Higher vocational teachers' solid knowledge includes not only knowledge and skills, but also the ability to spread knowledge and skills, as well as the educational thinking that transforms knowledge and skills into life wisdom, and always leads students to study knowledge with their own diligence and good thinking. The specialty setting of vocational education keeps up with the market demand, and the curriculum setting aims at technological progress. Successful higher vocational colleges and higher vocational teachers must guide and teach students to be brave in innovation and good at innovation with their own spirit of reform and innovation, scientific innovation methods and clear ideas of innovation, and be the guide of students' innovative thinking. Teaching students to do things is naturally what we teachers are better at doing. Only by serving the people, devoting ourselves and serving the country can vocational teachers become guides for students to devote themselves to the motherland. The elucidation of the moral dimension of ideological and political teachers in the course needs to run through the whole, the whole and all aspects of students' learning. Every general education teacher, professional teacher. Teachers, training teachers, corporate practice masters, and students contact with each of the staff are the main body of the analysis. The elucidation of the dimension of teachers' morality is not to reproach the teachers' morality, nor to kidnap the teachers' noble virtue. In the pursuit of art and Taoism, only when the teacher is in the first place, can the students' affinity, faith, devotion to teaching and effectiveness come first.

\subsection{Moral Education Element is the Core Element of Curriculum Ideology and Politics}

The socialist nature and development direction of China's higher education stipulate that the value of university courses lies in cultivating socialist builders and successors with correct political stand and value orientation. The key to highlight the educational value of the curriculum is to give full play to the moral function of the curriculum, which requires in-depth excavation of the moral elements in the curriculum. If the necessary moral elements are lacking, curriculum teaching will lose its soul, which will lead to the mutual separation of value shaping, knowledge imparting and ability cultivation in curriculum teaching, thus affecting the effect of education. However, under the long-term influence of 
instrumental rationalism in the field of education, China's curriculum teaching generally attaches more importance to knowledge than quality, attaches more importance to intellectual education than moral education, and attaches more importance to teaching than to educating people. As a result, many people have taken it for granted that value guidance, personality cultivation and spiritual construction are included in the "responsibility field" of ideological and political courses. In order to break this split situation and form a collaborative education force between other courses and ideological and political courses, it is necessary to do a clear job of value guidance in the teaching of professional courses, and silently carry out value edifying, so as to help students establish a correct world outlook, outlook on life and values. For the educational objects, the educational value of the curriculum is not only reflected in the increase of scientific knowledge and the improvement of professional skills, but also in the formation of political identity, value judgment, moral sentiment and other aspects, and the moral element is conducive to the broadened thinking, intellectual enlightenment, rational development of the educational resources. To further highlight the value of curriculum education, we must consciously and consciously excavate the moral elements contained in the curriculum, give play to its functions, and promote the organic integration of professional knowledge education and value guidance.

\section{THE EXAMPLE OF A TYPICAL CHARACTER}

\subsection{Carry out Ideological and Political Education for Students with Model Workers and Other Outstanding Typical Figures in the Industry}

To carry out ideological and political education with model workers and other outstanding typical figures in higher vocational education should be the most uncontroversial, easiest and early way of curriculum ideological and political education. For its necessity, important role and positive significance, vocational colleges have basically reached a broad consensus, and the basic level of implementation has been formed. However, as the interpretative dimension of curriculum ideology and politics, based on the diversity of professional courses, the long-term learning process, the universality of the audience, the repetition of skills acquisition and other characteristics, there are still three aspects that need to be paid attention to and explored in the actual use of industry typical character cases. First of all, in the subject, the choice of typical characters should have the characteristics of demonstration and affinity. "Teach, give from above, serve from below." Demonstration is the primary characteristic of model education. Aiming at the effectiveness of the ideological and political curriculum, the selection of role models can include: skilled post technical experts, model workers who have won high honors and awards, industry influential figures in a certain region, and other outstanding typical figures related to their major. The exemplary nature of an example does not mean being superior. The primary principle of ideological and political education is pertinence and affinity. In terms of the source of model selection, full consideration should be given to its physical and emotional connections with students. As far as possible, excellent senior students, outstanding graduates, excellent teachers and typical figures in the field outside the school should be selected. Secondly, in the content, the use of advanced examples of typical characters should highlight the incentive and epochal. In the past, the typical examples of role models are usually the work and study performance, the process of hard work, social recognition and other aspects, especially the outstanding personal qualities such as hard work, hard work, hard-working and uncomplaining. These contents are the natural expression of the inspiring characteristics of model education, which must be adhered to and carried forward. But at the same time, we must realize that under the trend of The Times, contemporary college students' cognition of model workers generally presents three characteristics of The Times: compared with the physical labor type, they prefer the knowledge-based and innovative model workers; While affirming the social value, it pays more attention to the realization of personal value such as personal happiness. It is easy to equate public idol with model worker image, etc. All of these characteristics need to choose epochal characters and examples, guide and expatiate epochal values, and plan a good example story. Moreover, it should have vividness in form. In professional courses to tell a good example story, it is necessary to do natural connection, people happen, by all means avoid " 5 minutes before class", two pieces of skin mechanically applied. When professional teachers tell good example stories, they should focus on familiar people and things they know. They should tell stories with great attention and reproduce scenes. By all means, they should not simply use the textbook with examples and preach with manuscripts.

\subsection{Leading the Cultivation and Practice of Socialist Core Values with the Example Education of Revolutionary Heroes}

In the new era, taking the revolutionary heroes as educational resources to carry out the ideological and political education of the curriculum has a positive guiding effect on the establishment of the outlook on life, values and world view of young individuals and university groups, and has a unique value implication for leading the cultivation and practice of the socialist core values $^{[5]}$. College students are in the alternating stage of youth and adolescence, and they are obviously uncertain and highly moldable. Model education to college 
students in the demonstration effect of the model by an example and practice to build a common life world, and make full use of teenagers of individual psychology, guide the education object from the learning model, follow the example of typical cause emotional resonance, increase psychological identity and promote behavior, make an example model demonstration and form a relative convergence between college students' practice of dynamic balance, eventually to the education object value guidance, coordination and motivation, personality, behavior norms ${ }^{[6]}$. As the carrier of ideological and political education information, revolutionary hero role models have vivid images of themselves and are able to accept and absorb the ideological and moral qualities required by the society to their members in a concrete, visual and personified form. The college students who have just entered the university campus are easily affected by the multiple impacts of the adult world and the real society, and fall into the psychological state of confusion, uneasiness and confusion. Ideological and political workers in colleges and universities must help them adjust their state in time and give correct guidance to the establishment of their world outlook, outlook on life and values. And the noble spirit and excellent quality displayed by the revolutionary heroes are the personification of the socialist core values. Revolutionary hero model in education to be able to abstract the system of socialist core values into concrete revolutionary hero image, thus more easily understood and accepted by the education object, effectively enhance the value of young students, then promote youth personal ambitions set and the realization of the value of life, become leading the socialist core values of cultivation and practice, and promote the construction of the socialist core value system and improve the driving force.

\section{CONCLUSION}

On the one hand, college teachers should cultivate people by virtue in the curriculum, and integrate their personal morality into the curriculum ideology and politics. We should give full play to the role models of typical characters. On the other hand, the implementation process should be closely combined with professional education. From the perspective of students' emotional dependence on professional courses, students' liking for a certain course is related to the practicality of the course and the academic foundation and teaching ability of the teachers. Therefore, the academic accomplishment and teaching experience of the teachers have become an important factor affecting the ideological and political effect of the course. Therefore, curriculum ideological and political education should be closely related to professional education, prompting professional teachers to play the role of cultural guidance, expand the spiritual dimension of professional knowledge, and achieve the goal of ideological and political education of professional courses. Avoid by all means go up professional course into ideological politics class, perhaps professional class and ideological politics class two pieces of skin. It is necessary to integrate the teacher's virtue and exemplary role into the teaching of professional courses harmoniously. Really do moisten things silently.

\section{REFERENCES}

[1] Qiu Ren-fu. The theoretical interpretation of "curriculum ideological and political course" and "curriculum ideological and political course" to the same peer[J]. Research on Ideological Education.2018(4): 109-113.

[2] Ren He-qun, Guan yin.Research on the Realization Approach and Practical Significance of Moral Education in Colleges and Universities[J].intelligence.2019(31).

[3] At the conference on ideological and political work in colleges and universities, $\mathrm{Xi}$ stressed that ideological and political work should be integrated into the whole process of teaching and create a new situation in the development of higher education. People's Daily, December 9, 2016.

[4] At the National Conference on Ideological and Political Work in Colleges and Universities, Xi Jinping stressed that ideological and political work should run through the whole process of education and teaching to create a new situation in the development of China's higher education. People's Daily, December 9, 2016.

[5] Liu Kun. On Role Model Education in Ideological and Political Education in Colleges and Universities [J]. Educational Exploration, 2011(5):138-139.

[6] Li Ji-li. Internal Mechanism and Practice Reflection of Model Education Method -- Taking Peking University Practice as an Example [J]. Research in Ideological Education, 2010(9):102-105. 